\title{
Anti-Inflammatory and Antioxidant Components from Hygroryza aristata
}

\author{
Yu-Ming Chung ${ }^{1, \dagger}$, Yu-Hsuan Lan ${ }^{2, \dagger}$, Tsong-Long Hwang ${ }^{1}$ and Yann-Lii Leu ${ }^{1, *}$
}

1 Graduate Institute of Natural Products, College of Medicine, Chang Gung University, Taoyuan 33302, Taiwan; E-Mails: u97831001@cc.kmu.edu.tw (Y.-M.C.); ht1@mail.cgu.edu.tw (T.-L.H.)

2 School of Pharmacy, China Medical University, Taichung 40402, Taiwan;

E-Mail: lanyh@mail.cmu.edu.tw (Y.-H.L.)

$\dagger$ These authors contributed equally to this work.

* To whom correspondence should be addressed; E-Mail: ylleu@mail.cgu.edu.tw;

Tel.: 886-3-2118800-5524; Fax: 886-3-2118236.

Received: 4 January 2011; in revised form: 21 February 2011 / Accepted: 23 February 2011 /

Published: 25 February 2011

\begin{abstract}
Twenty-six known compounds and two new compounds, including a new lignan, $\left(7 S^{*}, 8 R^{*}, 7^{\prime} R^{*}, 8^{\prime} S^{*}\right)$-icariol $\mathrm{A}_{2}-9-O-\beta$-xylopyranoside (1), and a new indole alkaloid, hygarine (2), were isolated from the extracts of Hygroryza aristata (Gramineae). The structures of all compounds were elucidated on the basis of NMR spectral analysis. The compounds (-)-epigallocatechin-3-O-gallate (4) and (-)-epicatechin-3-O-gallate (5) possess free radical scavenging activities and compound $\mathbf{1}$ could inhibit superoxide anion generation and elastase release by fMLP/CB-induced human neutrophils with IC50 values of $19.33 \pm 0.86$ and $24.14 \pm 1.59 \mu \mathrm{M}$, respectively.
\end{abstract}

Keywords: Hygroryza aristata; Gramineae; hygarine; anti-inflammatory; antioxidant 


\section{Introduction}

Hygroryza aristata (Gramineae) is a stoloniferous perennial plant widely distributed in tropical Asia [1]. This plant grows in paddy fields and ponds at 400-800 meters above sea level, often forming floating clusters in lakes and slow-flowing rivers, and is a forage favored by cattle. Nevertheless, to our knowledge the chemical and biological activities of this plant have not been reported previously. In the search for biologically active constituents from natural sources, we determined that the methanolic extract of this plant was able to scavenge DPPH free radicals. In the present study two new

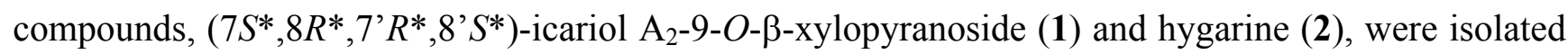
together with 26 known compounds from the extracts of the H. aristata (Figure 1). Several of these compounds were evaluated for their antioxidant and anti-inflammatory activities.

Figure 1. Structures of compounds 1-5.

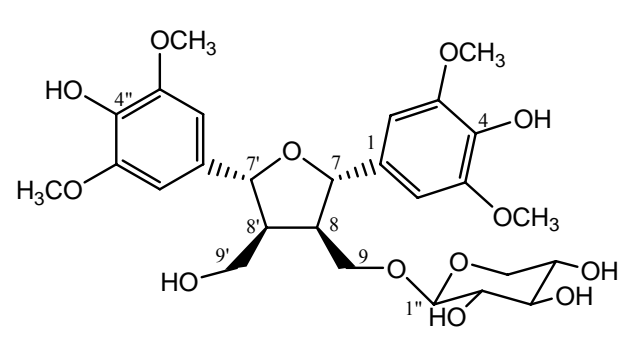

1<smiles>O=C(/C=C/c1ccc(O)cc1)Nc1ccccc1C(=O)O</smiles>

3

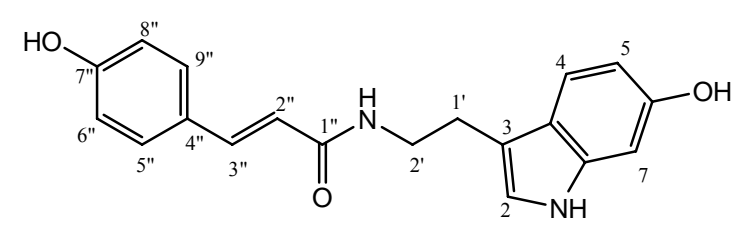

2

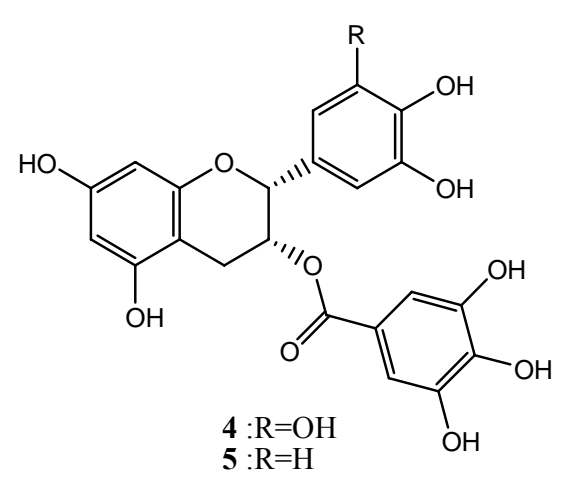

\section{Results and Discussion}

Compound 1 was obtained as a colorless syrup. Its IR spectrum exhibited hydroxyl and aromatic group absorption bands at $3,375 \mathrm{~cm}^{-1}$ and $1,517 \mathrm{~cm}^{-1}$, respectively. The UV spectrum revealed absorption maxima at 237 and $279 \mathrm{~nm}$. The ${ }^{1} \mathrm{H}-\mathrm{NMR}$ data (Table 1) showed two typical $1,3,4,5$-tetrasubstituted phenyl ring protons at $\delta 6.75$ and 6.79 (each $2 \mathrm{H}, s$ ), one anomeric proton at $\delta$ $4.23(1 \mathrm{H}, d, J=7.6 \mathrm{~Hz})$ and four methoxyl groups at $\delta 3.87(12 \mathrm{H}, \mathrm{s})$. Four methines at $\delta 2.34,2.46$, 5.01, 5.10 and two methylenes at $\delta 3.62,3.67,3.74,4.01$ were observed in the ${ }^{1} \mathrm{H}-\mathrm{NMR}$ and HMQC spectra. The ${ }^{13} \mathrm{C}$ signals at $\delta 66.0,70.2,73.9,77.0,104.3$ and the coupling constant $(J=7.6 \mathrm{~Hz})$ of anomeric proton suggested that $\mathbf{1}$ contained a $\beta$-D-xylose moiety. 
Table 1. ${ }^{1} \mathrm{H}$ - and ${ }^{13} \mathrm{C}-\mathrm{NMR}$ data for compound $\mathbf{1}$ (400 and $100 \mathrm{MHz}$ in methanol- $d_{4}$ ).

\begin{tabular}{ccl}
\hline \hline Position & $\boldsymbol{\delta}_{\mathrm{c}}$ & $\boldsymbol{\delta}_{\mathrm{H}}$ \\
\hline 1 & 133.2 & \\
2,6 & 103.9 & $6.75(2 \mathrm{H}, s)$ \\
3,5 & 148.3 & \\
4 & 135.2 & \\
7 & 83.6 & $5.10(1 \mathrm{H}, d, J=8.4 \mathrm{~Hz})$ \\
8 & 50.9 & $2.34(1 \mathrm{H}, m)$ \\
$9 \mathrm{a}$ & 68.6 & $3.62(1 \mathrm{H}, m)$ \\
$9 \mathrm{~b}$ & & $4.01(1 \mathrm{H}, d d, J=10.0,4.8 \mathrm{~Hz})$ \\
'' & 133.2 & \\
$2 ', 6$ & 104.0 & $6.79(2 \mathrm{H}, s)$ \\
3', 5' & 148.4 & \\
$4 '$ & 135.3 & \\
7' & 83.3 & $5.01(1 \mathrm{H}, d, J=8.4 \mathrm{~Hz})$ \\
8' & 53.5 & $2.46(1 \mathrm{H}, m)$ \\
9'a & 60.1 & $3.67(1 \mathrm{H}, m)$ \\
9'b & & $3.74(1 \mathrm{H}, d d, J=11.6,4.4 \mathrm{~Hz})$ \\
3, 5, 3', 5'-OCH 3 & 55.9 & $3.87(1 \mathrm{H}, s)$ \\
Xyl-1 & 104.3 & $4.23(1 \mathrm{H}, d, J=7.6 \mathrm{~Hz})$ \\
Xyl-2 & 73.9 & $3.20(1 \mathrm{H}, m)$ \\
Xyl-3 & 77.0 & $3.31(1 \mathrm{H}, m)$ \\
Xyl-4 & 70.2 & $3.48(1 \mathrm{H}, m)$ \\
Xyl-5 & 66.0 & $3.20(1 \mathrm{H}, m)$ \\
& & $3.84(1 \mathrm{H}, d d, J=6.4,2.4 \mathrm{~Hz})$ \\
\hline
\end{tabular}

HMBC correlations between H-1', H-2', H-6'/C-7' and $\mathrm{H}-1, \mathrm{H}-2, \mathrm{H}-6 / \mathrm{C}-7$ indicated that the 1,3,4,5- tetrasubstituted phenyl rings were connected to $\mathrm{C}-7$ ' and $\mathrm{C}-7$, respectively (Figure 2). The ${ }^{3} J$-correlation signals between $\mathrm{H}-9\left(\delta_{\mathrm{H}} 3.62,4.01\right)$ and $\mathrm{C}-1$ " $\left(\delta_{\mathrm{C}} 104.3\right)$ indicated the presence of a xylose unit attached at C-9.

Figure 2. HMBC and NOE Correlations of compound 1.

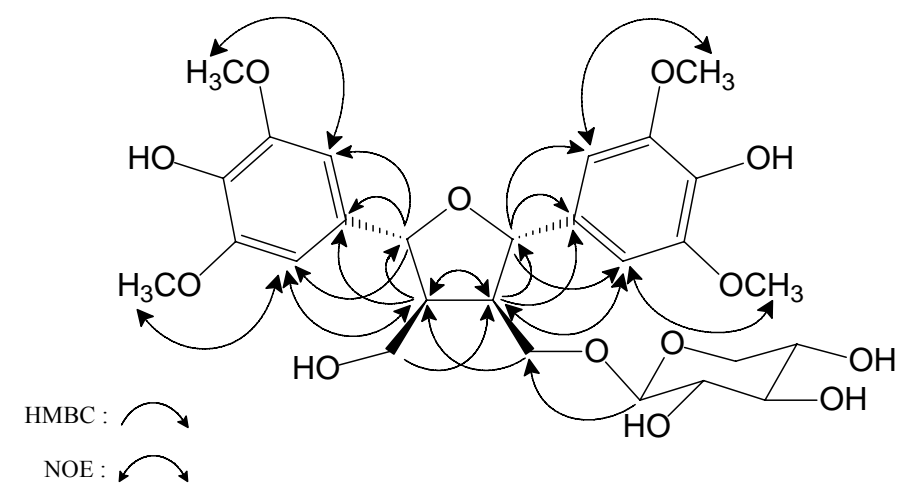

The planar structure of $\mathbf{1}$ is similar to that of icariol $\mathrm{A}_{2}-9-O-\beta$-xylopyranoside $[2,3]$. In a NOESY experiment, $\mathrm{H}-8 / \mathrm{H}-2,6$; H-8'/H-2', 6' and H-8/H-8' NOE correlations were observed, revealing that 
$\mathrm{H}-8,8$ ' and the two phenyls are a syn conformation. Based on these results, we established the relative configuration of $\mathbf{1}$ as shown in Figure 2. Thus, the structure of compound $\mathbf{1}$ was determined to be $\left(7 S^{*}, 8 R^{*}, 7^{\prime} R^{*}, 8^{\prime} S^{*}\right)$-icariol $\mathrm{A}_{2}-9-O-\beta$-xylopyranoside.

Compound 2 was obtained as a brown syrup with an elemental composition of $\mathrm{C}_{19} \mathrm{H}_{18} \mathrm{~N}_{2} \mathrm{O}_{3}$, as determined by its HRFAB-MS ([M+1 $]^{+} \mathrm{m} / \mathrm{z}$ 323.3734). The IR spectrum of 2 displayed absorption bands from a hydroxyl group $\left(3,404 \mathrm{~cm}^{-1}\right)$ and an amide group $\left(1,643 \mathrm{~cm}^{-1}\right)$. In the UV spectrum of 2 , absorption maxima were observed at $224(\mathrm{sh}), 288$, and $312(\mathrm{sh}) \mathrm{nm}$, revealing that the compound has an indole skeleton [4].

Table 2. ${ }^{1} \mathrm{H}$ - and ${ }^{13} \mathrm{C}-\mathrm{NMR}$ data for compound 2 (400 and $100 \mathrm{MHz}$ in acetone- $d_{6}$ ).

\begin{tabular}{crl}
\hline \hline Position & $\boldsymbol{\delta}_{\mathbf{C}}$ & $\boldsymbol{\delta}_{\mathbf{H}}$ \\
\hline 2 & 123.5 & $7.09(1 \mathrm{H}, d, J=2.4 \mathrm{~Hz})$ \\
3 & 112.1 & \\
4 & 112.0 & $7.19(1 \mathrm{H}, d, J=8.4 \mathrm{~Hz})$ \\
5 & 111.9 & $6.70(1 \mathrm{H}, d d, J=8.4,2.0 \mathrm{~Hz})$ \\
6 & 151.1 & \\
7 & 103.0 & $7.03(1 \mathrm{H}, d, J=2.0 \mathrm{~Hz})$ \\
8 & 132.0 & \\
9 & 128.8 & \\
1, & 26.1 & $2.89(2 \mathrm{H}, t, J=7.6 \mathrm{~Hz})$ \\
2 & 40.2 & $3.59(2 \mathrm{H}, d d, J=13.6,7.6 \mathrm{~Hz})$ \\
$1 "$ & 166.1 & \\
$2 "$ & 119.4 & $7.48(1 \mathrm{H}, d, J=16.0 \mathrm{~Hz})$ \\
3" & 139.6 & $6.49(1 \mathrm{H}, d, J=16.0 \mathrm{~Hz})$ \\
$4 ”$ & 127.3 & \\
5", 9" & 129.6 & $7.42(2 \mathrm{H}, d, J=8.4 \mathrm{~Hz})$ \\
6", 8" & 116.1 & $6.85(2 \mathrm{H}, d, J=8.4 \mathrm{~Hz})$ \\
7" & 159.3 & \\
1-NH & & $7.74(1 \mathrm{H}, \mathrm{br} . s)$ \\
3'-NH & & $7.30(1 \mathrm{H}, \mathrm{br} . s)$ \\
6-OH & & $8.86(1 \mathrm{H}, \mathrm{br} . s)$ \\
7"-OH & & $9.75(1 \mathrm{H}, \mathrm{br} . s)$ \\
\hline
\end{tabular}

In the ${ }^{1} \mathrm{H}-\mathrm{NMR}$ data of $\mathbf{2}$, shown in Table 2, the three mutually coupled aromatic protons at $\delta 6.70$ $(1 \mathrm{H}, d d, J=8.4,2.0 \mathrm{~Hz}), 7.03(1 \mathrm{H}, d, J=2.0 \mathrm{~Hz})$ and $7.19(1 \mathrm{H}, d, J=8.4 \mathrm{~Hz})$ were assigned to $\mathrm{H}-5$, $\mathrm{H}-7$ and $\mathrm{H}-4$ in the indole skeleton, respectively. The signal at $\delta 7.09(1 \mathrm{H}, \mathrm{d}, J=2.4 \mathrm{~Hz})$ was contributed by H-2 in the indole skeleton. In the aromatic region of the ${ }^{1} \mathrm{H}-\mathrm{NMR}$ spectrum, the signals at $\delta 6.85(2 \mathrm{H}, d, J=8.4 \mathrm{~Hz})$ and $7.42(2 \mathrm{H}, d, J=8.4 \mathrm{~Hz})$ indicated the presence of a 1,4-disubstituted benzene ring, and trans-olefinic protons appeared at $\delta 6.49(1 \mathrm{H}, d, J=16.0 \mathrm{~Hz})$ and $7.48(1 \mathrm{H}, d$, $J=16.0 \mathrm{~Hz}$ ). Therefore, the combined data for compound 2 indicated the presence of a partial coumaric acid. Two methylene proton signals at $\delta 2.89(2 \mathrm{H}, t, J=7.6 \mathrm{~Hz})$ and $3.59(2 \mathrm{H}, d d, J=13.6$, $7.6 \mathrm{~Hz}$ ) correlated with the carbon signal at $\delta 26.1$ (C-1') and 40.2 (C-2') in the HSQC experiment. The COSY spectrum of 2 showed two methylenes coupled with $\mathrm{NH}\left(\delta_{\mathrm{H}} 7.30\right)$. Thus, compound 2 contains a partial $\mathrm{NH}-\mathrm{CH}_{2}-\mathrm{CH}_{2}$ structure. The $\mathrm{HMBC}$ spectrum exhibited correlations between 
$\mathrm{H}-1$ '/C-2, C-3 and $\mathrm{C}-9, \mathrm{H}-2$ '/C-1" and C-1', H-2"/C-1", C-3", and C-4" indocatimg the three aforementioned structures to be connected as shown in Figure 3. In addition, the presence of a carbonyl group in the coumaric acid moiety connected to $\mathrm{NH}$ with an amide bond was further confirmed by the fragment at $\mathrm{m} / z 147$ in the FAB-MS spectrum. According to previous reports and the above NMR analysis, compound $\mathbf{2}$ was deduced to have the structure shown and it was named hygarine.

Figure 3. Significant correlations observed in HMBC of compound 2.

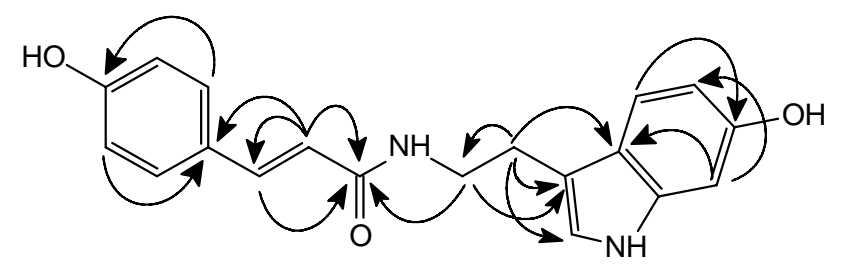

Twenty-six known compounds, including $N$-p-coumarylanthranilic acid (3) [5], (-)-epigallocatechin-3-O-gallate (4) [6], (-)-epicatechin-3-O-gallate (5) [7], L-tyrosine (6) [8], quercetin (7) [9], rutin (8) [9], kaempferol (9) [10], adenine (10) [11], adenosine (11) [11], inosine (12) [11], uracil (13) [12], uridine (14) [13], coumaric acid (15) [14], methyl coumarate (16) [15], ferulic acid (17) [16], $n$-hexacosyl ferulate (18) [17], vanillic acid (19) [18], $p$-hydroxybenzoic acid (20) [19], 2,6-dimethoxyquinone (21) [20], physcion (22) [21], cycloeucalenol (23) [22], squalane (24) [23], a $\beta$-sitosterol and stigmasterol mixture (25) [15], eicosanoic acid 2,3-dihydroxypropyl ester (26) [24], butcosanoic acid 2,3-dihydroxypropyl ester (27) [24] and sucrose (28) [25], were isolated and identified by comprehensive studies of their physical and spectral data.

Figure 4. Effect of $\left(7 S^{*}, 8 R^{*}, 7^{\prime} R^{*}, 8^{\prime} S^{*}\right)$-icariol $\mathrm{A}_{2}-9-O-\beta$-xylopyranoside (1) and $N$-p-coumarylanthranilic acid (3) isolated from $H$. aristata on generation of superoxide anion (left) and elastase release (right) in fMLP/CB-activated human neutrophils.
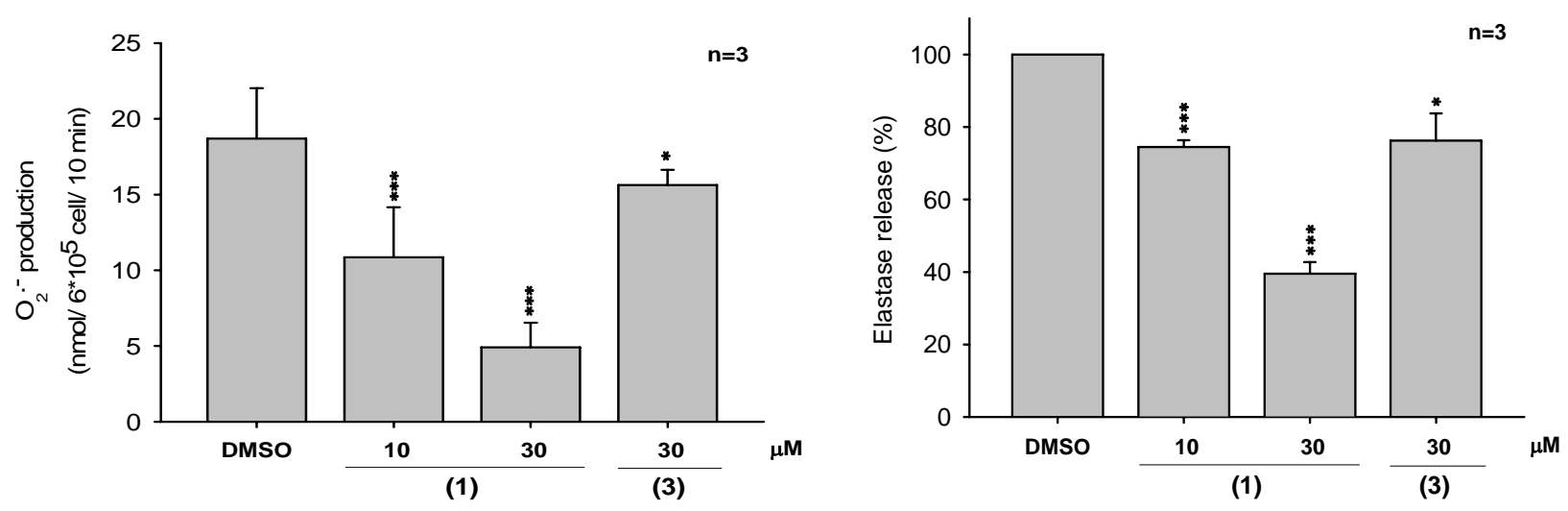

All data are expressed as mean \pm S.E.M. $(\mathrm{n}=3)$. $* \mathrm{P}<0.05$, $* * * \mathrm{P}<0.001$ compared with the control value.

Among all these compounds, several were evaluated for their antioxidant and anti-inflammatory activities. The inhibitory activity of $\left(7 S^{*}, 8 R^{*}, 7^{\prime} R^{*}, 8^{\prime} S^{*}\right)$-icariol $\mathrm{A}_{2}-9-O-\beta$-xylopyranoside (1) and $N$-p-coumarylanthranilic acid (3) against the inflammatory response in human neutrophils was 
investigated. Compound $\mathbf{1}$ showed moderate anti-inflammatory activities and further, it inhibited superoxide anion generation and elastase release by fMLP/CB-induced human neutrophils, with IC50 values of $19.33 \pm 0.86$ and $24.14 \pm 1.59 \mu \mathrm{M}$, respectively (Figure 4). In addition, the $n$-butanol soluble layer of the $H$. aristata methanolic extract was found to be a powerful scavenger of DPPH free radicals (Figure 5). In further bioactivity-guided investigation of the butanol layer, (-)-epigallocatechin-3-O-gallate (4) (2.92 g, 0.31\% of plant material), and (-)-epicatechin-3-O-gallate (5) (0.55 g, $0.06 \%$ ) were obtained; these compounds were the major components of $H$. aristata. Their radical scavenging activities were greater by approximately 3.8 and 3.1-fold, respectively, than that of $\alpha$-tocopherol (Figure 6). These results suggest that $H$. aristata could be a rich natural source of catechins due to its high content of these substances.

Figure 5. Effects of different crude extracts in scavenging DPPH radicals.

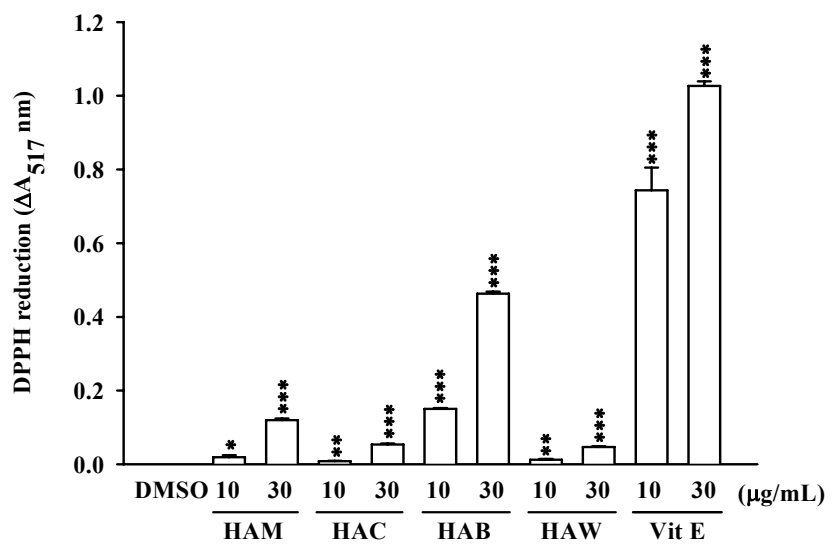

Reduction of DPPH was measured spectophotometrically at $517 \mathrm{~nm}$. All data are expressed as the mean \pm S.E.M. of three separate experiments. ${ }^{*} \mathrm{P}<0.05,{ }^{*} \mathrm{P}<0.01, * * * \mathrm{P}<0.001$ compared with the control value. HAM: H. aristata methanolic crude extract, $\mathrm{HAC}: H$. aristata $\mathrm{CHCl}_{3}$ layer, $\mathrm{HAB}$ : H. aristata $n$-BuOH layer, HAW: H. aristata water layer, Vit E: $\alpha$-tocopherol.

Figure 6. DPPH radical scavenging effects of compounds 1, 4 and 5 isolated from the $n$-butanol layer.

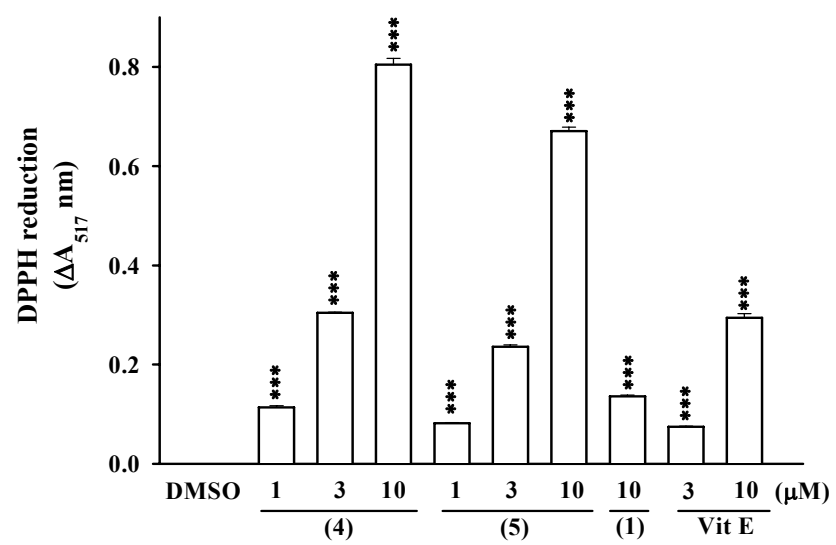

Reduction of DPPH was measured spectophotometrically at $517 \mathrm{~nm}$. All data are expressed as the mean \pm S.E.M. of three separate experiments. ${ }^{* * *} \mathrm{P}<0.001$ compared with the control value. 


\section{Experimental}

\subsection{General}

Melting points were measured on a Yanagimoto MP-S3 micro melting point apparatus and are uncorrected. The UV spectra were recorded on a Hitachi U-3010 spectrophotometer in MeOH solution. The IR spectra were recorded on a Jasco IR Report-100 spectrophotometer as $\mathrm{KBr}$ discs. The ${ }^{1} \mathrm{H}-$ and ${ }^{13} \mathrm{C}-\mathrm{NMR}$ spectra were recorded on Bruker Avance-400 spectrometer. Chemical shifts are shown in $\delta$ values with tetramethylsilane as internal reference. The mass spectra were performed in the EI or FAB (matrix: glycerol) mode on a VG 70-250 S spectrometer. Specific rotations were determined on a Jasco P-1010 polarimeter.

\subsection{Plant Material}

Hygroryza aristata was collected and authenticated by Prof. C. S. Kouh at I-Lang, Taiwan. A voucher specimen (CGU-HA-1) was deposited in the herbarium of Chang Gung University, Taoyuan, Taiwan.

\subsection{Extraction and Isolation}

Dry H. aristata $(948 \mathrm{~g})$ was extracted with $\mathrm{MeOH}(6 \mathrm{~L} \times 6)$ under reflux for 8 hours and concentrated to give a brown syrup (122.0 g). The syrup was suspended in $\mathrm{H}_{2} \mathrm{O}$ and partitioned successively with $\mathrm{CHCl}_{3}$ and $n-\mathrm{BuOH}$. The $\mathrm{CHCl}_{3}$ extract $(17.0 \mathrm{~g})$ was subjected to column chromatography over silica gel and eluted with a $\mathrm{CHCl}_{3}$ and $\mathrm{MeOH}$ step gradients to afford eight fractions. Repeated column chromatography of the first fraction, over silica gel with $n$-hexane and EtOAc mixtures yielded squalane $(\mathbf{2 4}, 2.3 \mathrm{mg})$. The second and third fractions were treated as the first fraction to obtain $n$-hexacosyl ferulate $(\mathbf{1 8}, 7.2 \mathrm{mg}), p$-hydroxybenzoic acid (20, $5.0 \mathrm{mg}), 2,6$-dimethoxyquinone $(\mathbf{2 1}, 2.2 \mathrm{mg})$ and physcion $(\mathbf{2 2}, 1.5 \mathrm{mg})$, separately. The fourth fraction was repeatedly chromatographed over silica gel with $\mathrm{CHCl}_{3}$ and $\mathrm{MeOH}(18: 1)$ to afford cycloeucalenol (23, $7.1 \mathrm{mg}), \beta$-sitosterol \& stigmasterol mixture $(\mathbf{2 5}, 100.0 \mathrm{mg})$, eicosanoic acid 2,3-dihydroxypropyl ester (26, $5.2 \mathrm{mg}$ ) and butcosanoic acid 2,3-dihydroxypropyl ester (27, $12.1 \mathrm{mg})$, successively. The fifth fraction was repeatedly column chromatographed over silica gel with $\mathrm{CHCl}_{3}-\mathrm{MeOH}$ gradients to give coumaric acid $(\mathbf{1 5}, 11.5 \mathrm{mg})$ and methyl coumarate $(\mathbf{1 6}, 5.3 \mathrm{mg})$. The sixth fraction was purified by recrystallisation to afford vanillic acid $(\mathbf{1 9}, 2.5 \mathrm{mg})$.

The $n$-BuOH layer (18.4 g) was applied on Diaion HP-20 gel and eluted with gradients of $\mathrm{H}_{2} \mathrm{O}$ and $\mathrm{MeOH}$ to give eight fractions. The second fraction was subjected to column chromatography over silica gel and eluted with a $\mathrm{CHCl}_{3}$ and $\mathrm{MeOH}$ step gradient to afford L-tyrosine $(\mathbf{6}, 10.0 \mathrm{mg})$, inosine $(12,11.0 \mathrm{mg})$ and uridine $(\mathbf{1 4}, 20.0 \mathrm{mg})$, successively. The third fraction was chromatographed on silica gel column and eluted with $\mathrm{CHCl}_{3}$ and $\mathrm{MeOH}$ mixtures to give adenine (10, $\left.15.6 \mathrm{mg}\right)$ and uracil $(\mathbf{1 3}, 5.6 \mathrm{mg})$. The fourth fraction was filtered to give adenosine $(\mathbf{1 1}, 20.3 \mathrm{mg})$. The fifth fraction was 
repeatedly column chromatographed over silica gel with $\mathrm{CHCl}_{3}-\mathrm{MeOH}$ gradients to give quercetin (5, $3.5 \mathrm{mg}$ ), kaempferol (7, $10.0 \mathrm{mg})$, (-)-epigallocatechin-3-O-gallate (4, 2,919.3 mg) and (-)-epicatechin-3-O-gallate $(5,552.0 \mathrm{mg})$. The seventh fraction was also rechromatographed over silica gel and eluted with EtOAc to give $\left(7 S^{*}, 8 R^{*}, 7^{\prime} R^{*}, 8^{\prime} S^{*}\right)$-icariol $\mathrm{A}_{2}-9-O-\beta$-xylopyranoside $(1,15.7 \mathrm{mg})$ and rutin $(6,3.2 \mathrm{mg})$. The eighth fraction was repeatedly column chromatographed over silica gel with $\mathrm{CHCl}_{3}-\mathrm{MeOH}$ gradients to give hygarine $(2,3.0 \mathrm{mg}), N$ - $p$-coumarylanthranilic acid $(\mathbf{3}, 8.6 \mathrm{mg})$ and ferulic acid (17, $2.8 \mathrm{mg})$, separately.

The $\mathrm{H}_{2} \mathrm{O}$ layer $\left(82.1 \mathrm{~g}\right.$ ) was applied on Diaion HP-20 gel and eluted with gradients of $\mathrm{H}_{2} \mathrm{O}$ and $\mathrm{MeOH}$ to give four fractions. The first fraction was chromatographed on Sephadex LH-20 column and eluted with gradients of $\mathrm{H}_{2} \mathrm{O}$ and $\mathrm{MeOH}$ to afford sucrose $(\mathbf{2 8}, 20.5 \mathrm{mg}$ ). The second fraction was repeatedly column chromatographed over Sephadex LH-20 with $\mathrm{H}_{2} \mathrm{O}: \mathrm{MeOH}$ gradients to give uridine (14, $20.0 \mathrm{mg})$.

\subsection{DPPH Free-Radical Scavenging Activity}

The scavenging activity of the DPPH radical was assayed by the modified method of Shimada et al. [26]. The absorbance was measured at $517 \mathrm{~nm}$. Lower absorbance of the reaction mixture indicates higher free-radical scavenging activity. The DPPH radicalscavengingactivity (\%) was calculated by the following equation:

scavenging activity $(\%)=\left(1-A_{\text {sample }} / A_{\text {control }}\right) \times 100 \%$

\subsection{Preparation of Human Neutrophils}

Human neutrophils from venous blood of healthy, adult volunteers (20-30 years old) were isolated with a standard method of Dextran sedimentation prior to centrifugation in Ficoll Hypaque gradient and hypotonic lysis of erythrocytes. Purified neutrophils that contained $>98 \%$ viable cells, as determined by trypan blue exclusion, were resuspended in HBSS buffer at $\mathrm{pH} 7.4$, and kept at $4{ }^{\circ} \mathrm{C}$ before use.

\subsection{Measurement of Superoxide Anion $\left(\mathrm{O}_{2}{ }^{--}\right)$Generation}

The measurement of the generation of $\mathrm{O}_{2}{ }^{--}$was based on the superoxide dismutase (SOD)-inhibitable reduction of ferricytochrome $c$ [27]. In brief, after supplementing with ferricytochrome $c(0.5 \mathrm{mg} / \mathrm{mL})$, neutrophils $\left(6 \times 10^{5} / \mathrm{mL}\right)$ were equilibrated at $37{ }^{\circ} \mathrm{C}$ for 2 min and incubated with either control or different concentrations of tested compounds for $5 \mathrm{~min}$. Cells were activated by fMLP $(0.1 \mu \mathrm{M})$ or PMA $(5 \mathrm{nM})$ for $10 \mathrm{~min}$. When fMLP was used as stimulant, cytochalasin $\mathrm{B}(\mathrm{CB}, 1 \mu \mathrm{g} / \mathrm{mL})$ was incubated for $3 \mathrm{~min}$ before peptide activation. The changes in absorbance with the reduction of ferricytochrome $c$ at $550 \mathrm{~nm}$ were continuously monitored in a double-beam, six-cell positioner spectrophotometer with constant stirring. Calculation is based on the difference of the reactions with and without SOD $(100 \mathrm{U} / \mathrm{mL})$ divided by the extinction coefficient for the reduction of ferricytochrome $c(\varepsilon=21.1 / \mathrm{mM} / 10 \mathrm{~mm})$. 
$\left(7 S^{*}, 8 R^{*}, 7^{\prime} R^{*}, 8^{\prime} S^{*}\right)$-Icariol $A_{2}-9-O-\beta$-xylopyranoside (1). Colorless syrup. Formula: $\mathrm{C}_{27} \mathrm{H}_{36} \mathrm{O}_{13} .[\alpha]_{\mathrm{D}}$ $+0.63^{\circ}$ ( $c$ 0.35, MeOH). UV $\lambda_{\max } \mathrm{nm}(\log \varepsilon): 237$ (2.89), 279 (2.70). IR $v_{\max } \mathrm{cm}^{-1}: 3,375,1,613,1,517$, 1,113. FAB-MS $m / z$ (rel. int.\%): 591 ( [M+Na $\left.]^{+}, 8\right), 175$ (7), 161 (9), 153 (6), 149 (20), 133 (9). ${ }^{1} \mathrm{H}-$ and ${ }^{13} \mathrm{C}-\mathrm{NMR}$ : see Table 1.

Hygarine (2). Brown syrup. UV $\lambda_{\max } \mathrm{nm}$ (loge): 224 (sh) (3.52), 288 (3.27), 312 (sh) (3.22). IR $v_{\max }$ $\mathrm{cm}^{-1}:$ 3,404, 1,643, 1,048. FAB-MS m/z (rel. int.\%): 323 ([M+1] $\left.]^{+}, 12\right), 147$ (30), 55 (100), 94 (30). HRFAB-MS: Anal. Calcd. for $\mathrm{C}_{19} \mathrm{H}_{18} \mathrm{~N}_{2} \mathrm{O}_{3} 323.3726$, found 323.3734. ${ }^{1} \mathrm{H}$ - and ${ }^{13} \mathrm{C}-\mathrm{NMR}$ : see Table 2.

\section{Conclusions}

Two new compounds, $\left(7 S^{*}, 8 R^{*}, 7^{\prime} R^{*}, 8^{\prime} S^{*}\right)$-icariol $\mathrm{A}_{2}-9-O-\beta$-xylopyranoside (1) and hygarine (2), together with twenty-six known compounds, were isolated from the extracts of Hygroryza aristata. (-)-Epigallocatechin-3-O-gallate (4) and (-)-epicatechin-3-O-gallate (5) possess free radical scavenging activities. (7 $\left.S^{*}, 8 R^{*}, 7^{\prime} R^{*}, 8^{\prime} S^{*}\right)$-Icariol $\mathrm{A}_{2}-9-O-\beta$-xylopyranoside (1) could inhibit superoxide anion generation and elastase release by $\mathrm{fMLP} / \mathrm{CB}$-induced human neutrophils with $\mathrm{IC}_{50}$ values of $19.33 \pm 0.86$ and $24.14 \pm 1.59 \mu \mathrm{M}$, respectively.

\section{Acknowledgements}

This work was supported by a program project of the National Science Council (NSC 92-2323-B-182-001). We are grateful to the National Center for High-performance Computing for computer time and facilities. We also thank Miss L. N. Lai, National Cheng Kung University, for measuring mass spectra.

\section{References}

1. Hsu, C.C.; Kuoh, C.S.; Lin, W.C.; Liu, H.Y. Flora of Taiwan, 2nd ed.; Epoch Publishing Co., Ltd.: Taipei, Taiwan, 2000; Volume 5, pp. 320-321.

2. Takara, K.; Matsui, D.; Wada, K.; Ichiba, T.; Chinen, I.; Nakasone, Y. New phenolic compounds from Kokuto, non-centrifuged cane sugar. Biosci. Biotechnol. Biochem. 2003, 67, 376-379.

3. Su, D.G.; Tang, W.Z.; Hu, Y.C.; Liu, Y.B.; Yu, S.S.; Ma, S.G.; Qu, J.; Yu, D.Q. Lignan glycosides from Neoalsomitra integrifoliola. J. Nat. Prod. 2008, 71, 784-788.

4. Ghosal, S.; Srivastava, R.S. $\beta$-Phenethylamine, tetrahydroisoquinoline and indole alkaloids of Desmodium tiliaefolium. Phytochemistry 1973, 12, 193-197.

5. Ponchet, M.; Jean, F.B.; Hauteville, M.; Riccl, P. Dianthramides ( $N$-benzoyl and $N$-paracoumarylanthranilic acid derivativies) from elicited tissues of Dianthus caryophyllus. Phytochemistry 1988, 27, 2725-2730.

6. Goetz, G.; Fkyerat, A.; Metais, N. Resistance factors to grey mould in grape berries: Identification of some phenolics inhibitors of Botrytis cinerea stilbene oxidase. Phytochemistry 1999, 52, 759-767.

7. Fan, W.; Tezuka, Y.; Kadota, S. Proly endopeptidase inhibitory activity of fourteen kampo formulas and inhibitory constituents of Tokaku-joki-to. Chem. Pharm. Bull. 2000, 48, 1055-1061. 
8. Houck, D.R.; Hanners, J.L.; Unkefer, C.J. Biosynthesis of pyrroloquinoline quinine.1. Identification of biosynthetic precursors using ${ }^{13} \mathrm{C}$ labeling and NMR spectroscopy. J. Am. Chem. Soc. 1988, 110, 6920-6921.

9. Liu, J.X.; Di, D.L.; Shi, Y.P. Diversity of chemical constituents from Saxifraga montana H.. J. Chin. Chem. Soc. 2008, 55, 863-870.

10. Slimestad, R.; Andersen, M.; Francis, G.W.; Marston, A.; Hostettmann, K. Syringetin 3-O-(6"-acetyl)- $\beta$-glucopyranoside and other flavonols from needles of Norway spruce, Picea abies. Phytochemistry 1995, 40, 1537-1542.

11. Wu, T.S.; Leu, Y.L.; Chan, Y.Y. Aristolochic acids as a defensive substance for the Aristolochiaceous plant-feeding swallowtail butterfly, Pachliopta aristolochiae interpositus. J. Chin. Chem. Soc. 2000, 47, 221-226.

12. Kitajima, J.; Tanaka, T.; Ida, Y. Water-soluble constituents of fennel. IX. glucosides and nucleosides. Chem. Pharm. Bull. 1999, 47, 988-992.

13. Sako, M.; Kawada, H. A new and efficient synthetic method for ${ }^{15} \mathrm{~N}_{3}$-labeled cytosine nucleoside: dimroth rearrangement of cytidine $\mathrm{N}_{3}$-oxides. J. Org. Chem. 2004, 69, 8148-8150.

14. Lin, Y.L.; Wang, W.Y.; Kuo, Y.H.; Chen, C.F. Nonsteroidal constituents from Solanum incanum L. J. Chin. Chem. Soc. 2000, 47, 247-251.

15. Leu, Y.L.; Chan, Y.Y.; Hsu, M.Y.; Chen, I.S.; Wu, T.S. The constituents of the stem and roots of Aristolochia foveolata. J. Chin. Chem. Soc. 1998, 45, 539-541.

16. Kosuge, K.; Mitsunaga, K.; Koike, K.; Ohmoto, T. Studies on the constituents of Ailanthus integrifolia. Chem. Pharm. Bull. 1994, 29, 1669-1671.

17. Shen, C.C.; Syu, W.J.; Li, S.Y.; Lin, C.H.; Lee, G.H.; Sun, C.M. Antimicrobial activities of naphthazarins from Arnebia euchroma. J. Nat. Prod. 2002, 65, 1857-1862.

18. Chen, C.Y.; Chang, F.R.; Teng, C.M.; Wu, Y.C. Cheritamine, a new $N$-fatty acyl tryptamine and other constituents from the stems of Annona cherimola. J. Chin. Chem. Soc. 1999, 46, 77-86.

19. Wu, T.S.; Yeh, J.H; Wu, P.L. The heartwood constituents of Tetradium glabrifolium. Phytochemistry 1995, 40, 121-124.

20. Lin, W.Y.; Kuo, Y.H.; Chang, Y.L.; Teng, C.M.; Wang, E.C.; Tsutomu, I.; Chen, I.S. Anti-platelet aggregation and chemical constituents from the rhizome of Gynura japonica. Planta Med. 2003, 69, 757-764.

21. Wang, E.C.; Shih, M.H.; Liu, M.C.; Chen, M.T.; Lee, G.H. Studies on constituents of Saururus chinensis. Heterocycles 1996, 43, 969-975.

22. Lee, C.K.; Chang, M.H. The chemical constituents from the heartwood of Eucalyptus citriodora. J. Chin. Chem. Soc. 2000, 47, 555-560.

23. Wu, T.S.; Chang, F.C.; Wu, P.L.; Kaoh, C.S.; Chen, I.S. Constituents of Tetradium glabrifolium. J. Chin. Chem. Soc. 1995, 42, 929-934.

24. Susumu, K.; Toshiro, I.; Ken, Y.; Sakae, Y.; Michio, T. (+)- $\alpha$-Viniferin an antiflammatory compound from Caragana chamlagu root. Chem. Pharm. Bull. 1990, 38, 432-435.

25. Wolters, A.M.; Jayawickrama, D.A.; Larive, C.K.; Sweedler, J.V. Capillary isotachophoresis/NMR: Extension to trace impurity analysis and improved instrumental coupling. Anal. Chem. 2002, 74, 2306-2313. 
26. Shimada, K.; Fujikawa, K.; Yahara, K.; Nakamura, T. Antioxidative properties of xanthan on the autoxidation of soybean oil in cyclodextrin emulsion. J. Agric. Food Chem. 1992, 40, 945-948.

27. Hwang, T.L.; Su, Y.C.; Chang, H.L.; Leu, Y.L.; Chung, P.J.; Kuo, L.M.; Chang, Y.J. Suppression of superoxide anion and elastase release by $\mathrm{C}_{18}$ unsaturated fatty acids in human neutrophils. $J$. Lipid Res. 2009, 50, 1395-1408.

Sample Availability: Samples of the compounds 1, 3-28 are available from the authors.

(C) 2011 by the authors; licensee MDPI, Basel, Switzerland. This article is an open access article distributed under the terms and conditions of the Creative Commons Attribution license (http://creativecommons.org/licenses/by/3.0/). 